\title{
The Development of Group Guidance Models to Prevent Potential Homosexual Threats in University
}

\author{
Hidayani Syam, Nevi Yarni, Muri Yusuf
}

\begin{abstract}
This study was aimed to develop a group guidance model in order to prevent the potential threat of homosexuality in university. Homosexual behavior has occurred in the wider community. The perpetrators openly show their existence to the world in various ways and it is as if they ask for the world's recognition of the existence of their people. This phenomenon is a threat to the younger generation. The rise of homosexual cases today in universities has become one of the problems for counseling lecturers and it is necessary to find alternative solutions so that the potential threat of homosexuality can be prevented. This study used the R\&D method with the ADDIE approach (analyze, design, develop, implementation and evaluation). Based on the findings in the field, it is known that the validity of the research product has an average value of 0.80 valid. The model book has an average score of 0.817 and is classified as valid. Students' book has an average score of 0.796 and is classified as valid. Students' book has an average score of 0.794 and is classified as valid. The practicality of the research product has an average score of 4.2 and is classified as very practical. The model book has an average score of 4.20 and is classified as very practical. The lecturers' book has an average score of 4.21 and is classified as very practical. The student's book has an average score of 4.20 and is classified as very practical.
\end{abstract}

Keywords: Group Guidance, Homosexual Learning Model

\section{INTRODUCTION}

Sexual deviation has become a hot topic of conversation and has even been the subject of debate throughout human civilization. Humans who abide by norms strongly condemn various acts of sexual deviation, however, all of them are challenged by those who feel aggrieved by this view, which has led to intense debates in order to gain recognition from various parties. This contradiction became even more acute with the emergence of speeches by those who supported the LGBT (lesbian, gay, bisexual transgender) movement, which was started in the Western world. The birth of this movement began with the formation of the Gay Liberation Front (GLF) in London in 1970. What inspired this movement was the liberation of the previous birth of LGBT in the United States in 1969 at Stonewall [5] [9] [12] [14] [20 ].

Manuscript received on April 16, 2021.

Revised Manuscript received on April 24, 2021.

Manuscript published on April 30, 2021.

*Correspondence Author

Hidayani Syam*, Mahasiswa, Universitas Negeri Padang, Indonesia.

Nevi Yarni, Professor, Mahasiswa, Universitas Negeri Padang, Indonesia.

Muri Yusuf, Professor, Mahasiswa, Universitas Negeri Padang, Indonesia.

(C) The Authors. Published by Blue Eyes Intelligence Engineering and Sciences Publication (BEIESP). This is an open access article under the CC BY-NC-ND license (http://creativecommons.org/licenses/by-nc-nd/4.0/)
Published By:

Blue Eyes Intelligence Engineering \& Sciences Publication

(c) Copyright: All rights reserved.

As many as 2,000,000-3,700,000 US children under the age of 18 may have lesbian, gay, bisexual, or transgender parentage, and about 200,000 are raised by same-sex partners [4] [6] [11] [16] [18] [22]. In Indonesia alone, based on statistical data in 2003 the number of LGBT people was recorded at 8-10 million. The growing population of the people was accompanied by the phenomenon of shifting people's views on homosexuality. The increasing number of homosexuals shows their existence in Indonesia [1] [8]. Until now, homosexuality has often become a contradictory issue in society, debates that have arisen regarding homosexuality are related to the factors causing it and how a group of people reacts to it.

From the various research results that have been carried out, it can be seen that it is necessary to develop a new intervention in the field of guidance and counseling, especially group guidance, considering that the counseling services that have been carried out by counselors have preexisting limitations and weaknesses so that efforts to prevent and alleviate homosexual problems are not optimal handling.

One alternative that can be given to prevent homosexual acts from growing so that students can channel their sexual orientation correctly is by playing shows or giving the right films to students [17] [24]. Provision of shows/films as a coping strategy apart from providing entertainment can also have a positive effect in preventing homosexuality at IAIN Bukittinggi by seeing the characters in the film as role models. The reason for giving this film is the film has several advantages, namely entertaining, educating, and empowering [3]

\section{METHOD}

The method in this research is the development method (R\&D) with the ADDIE model (Analysis, Design, Development, Implementation, and Evaluation). The analysis stage comprises needs analysis, student analysis, literature analysis, and objective analysis. The design stage consists of the design of a model book, a lecturer book, and a student book. The development stage tests the validity of the product. The implementation and evaluation stages carried out a practicality test.

\section{RESULT AND DISCUSSION}

\section{Product Validity \\ a. BKpTSK Model Book}

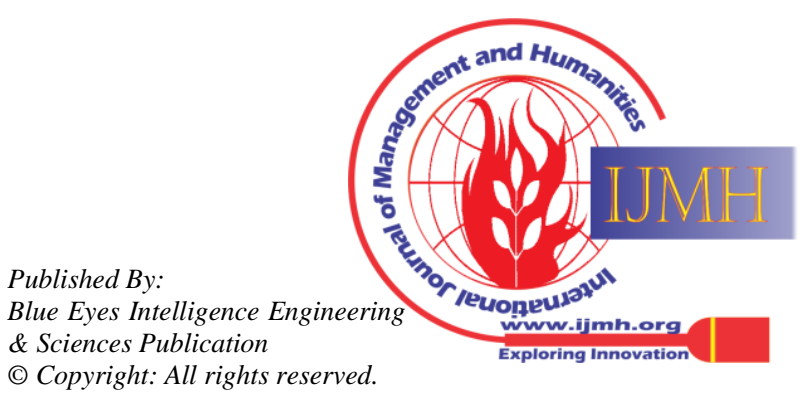




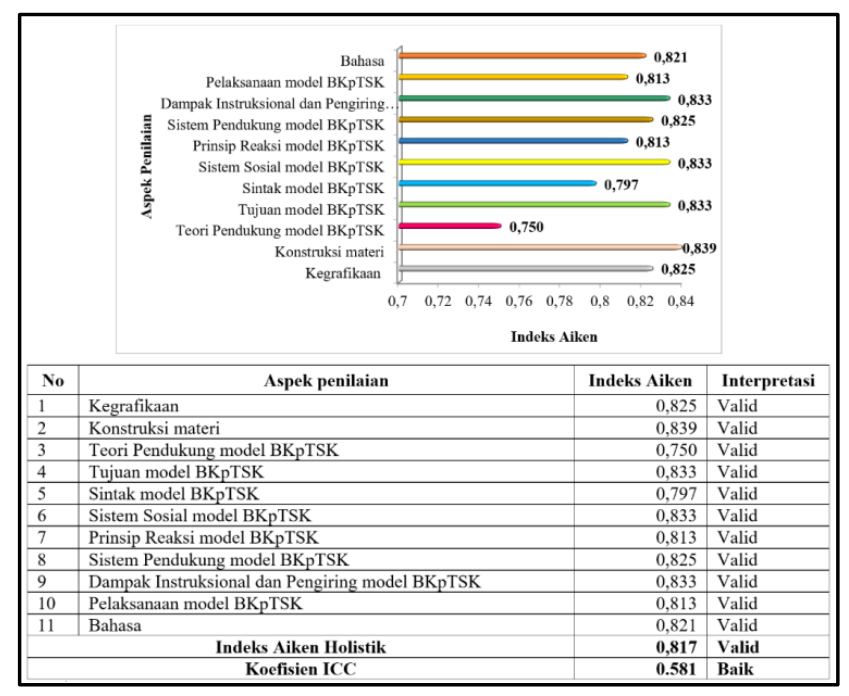

Figure 1 The Result of the model book validy test BKpTSK[27]

Based on Figure 1, it provides information that the results of the validity test data analysis of the BKpTSK model book prototype have valid criteria, with a holistic Aiken index value of 0.817 . Based on the results of the data analysis of the validator team's assessment of the BKpTSK model book prototype, the Intra-class Correlation Coefficient (ICC) value was 0.581. The results of the analysis indicate that the consistency/reliability of the validator's assessment of the BKpTSK model book prototype has good reliability. The validation and reliability test results of the BKpTSK model book have valid, reliable, and usable criteria.

\section{b. BKpTSK Lecturer Book}

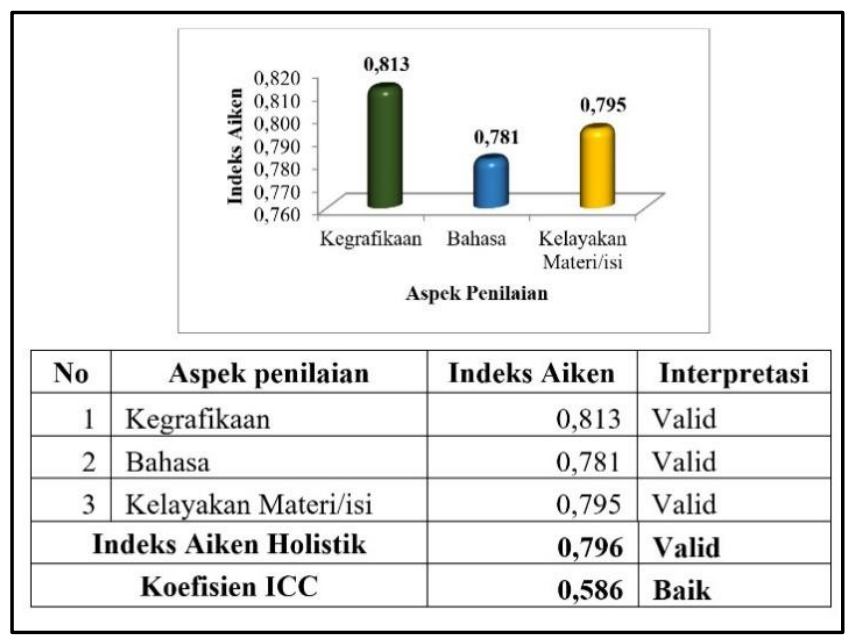

Figure 2. The Result of the teachers book validty test

$$
\text { [27] }
$$

The data in Figure 2 explained that the results of the analysis of the validator team's assessment of the lecturer book prototype based on the BKpTSK model have valid criteria with a holistic Aiken index value of 0.796. In the results of the book validity test, the lecturer book based on the BKpTSK model of the graphic aspect has the highest Aiken index with a value of 0.813 . Moreover, from the results of the data analysis of the validator team's assessment of the lecturer book prototype based on the BKpTSK model, the Intra-class Correlation Coefficient (ICC) value was 0.586 . The results of this analysis can be

Published By: carried out by the validator team on the prototype of the lecturers' book based on the BKpTSK model has good BKpTSK model lecturer book have valid, reliable criteria and can be used for counseling guidance services.

\section{c. BKpTSK Students Book}

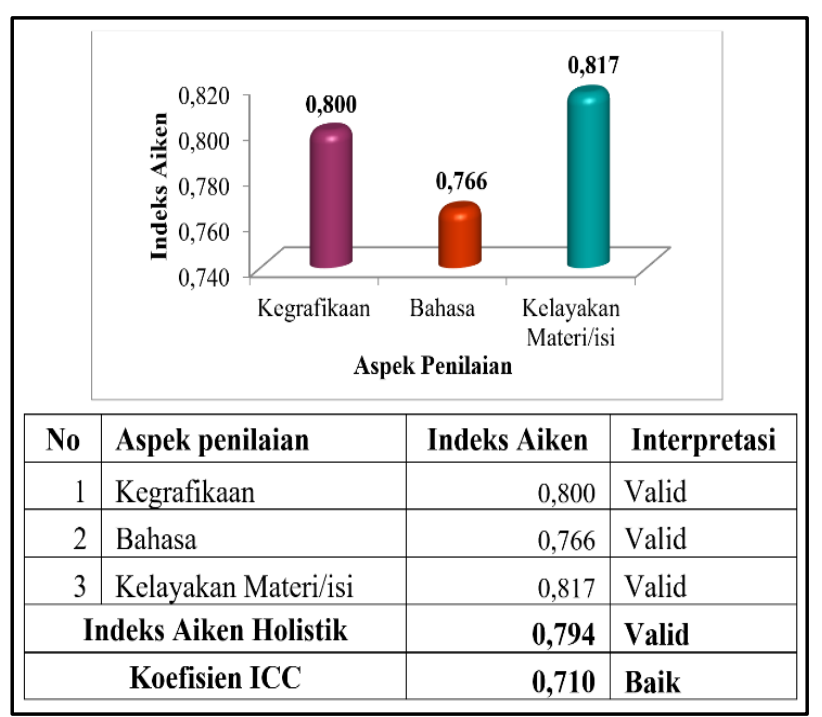

Figure 3. The result of the students book validity test [27]

Based on Figure 3, it can be explained that the results of the analysis of the validator team's assessment of the student book prototype based on the BKpTSK model have a holistic Aiken index value of 0.794, the achievement of this value is in the valid qualification range. In the results of the validity test of student books based on the BKpTSK model, the aspect of material/content assessment has the highest Aiken index with a value of 0.817 .

Furthermore, the results of the data analysis of the validator team's assessment of the student book prototype based on the BKpTSK model shown in the Figure, it was found that the Intra-class Correlation Coefficient (ICC) value was 0.710 . The results of this analysis can be interpreted that the consistency/reliability of the assessment carried out by the validator team on the student book prototype based on the BKpTSK model has good reliability. The validation and reliability test results of the BKpTSK model student book have valid, reliable criteria and can be used for counseling guidance services.

\section{Product Practicality \\ a. BKpTSK Model Book}




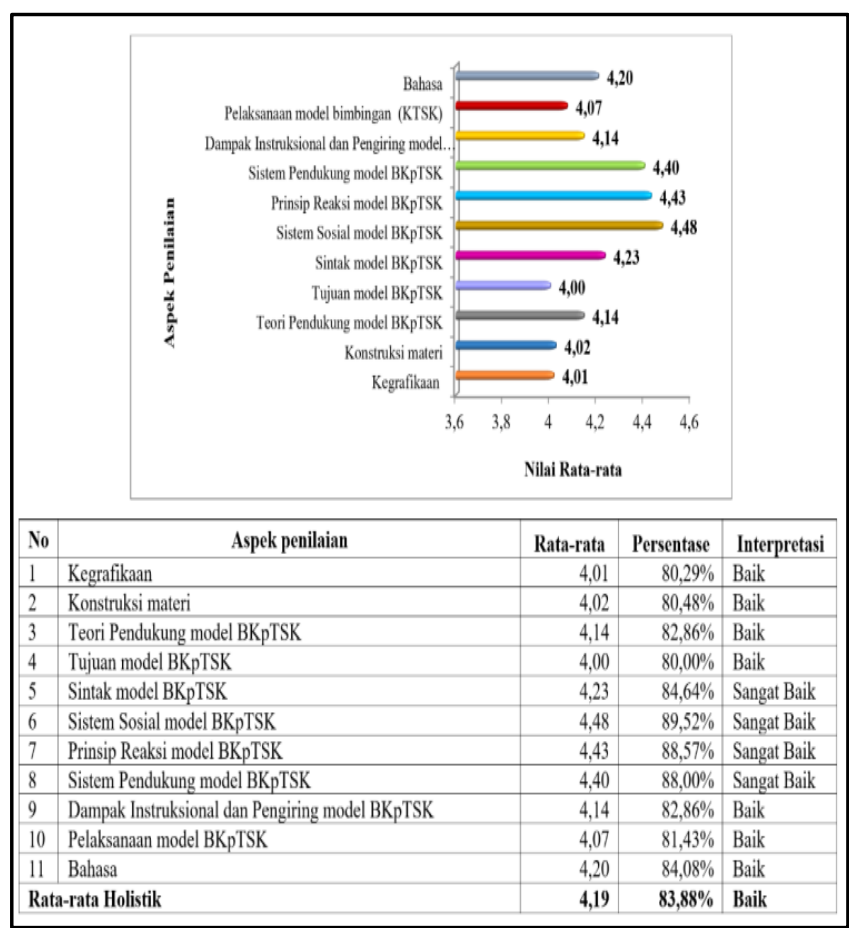

\section{Figure 4. The result of the model book practicality test BKpTSK [27]}

It can be explained that the BKpTSK model book prototype is considered good by BK lecturers with a holistic average score of 4.19 . Of the 11 assessment aspects in the BKpTSK model book prototype, there are 4 aspects of assessment that have very good interpretations and 7 aspects of assessment that have good interpretations. The highest average score on the assessment of the BKpTSK model book prototype in the FGD stage is the discussion of the BKpTSK model social system with a value of 4.48 . Meanwhile, the lowest average value is in the aspect of discussing the objectives of the BKPTSK model with an average value of 4.00 and good interpretation.

\section{b. BKpTSK Lecturer Book}

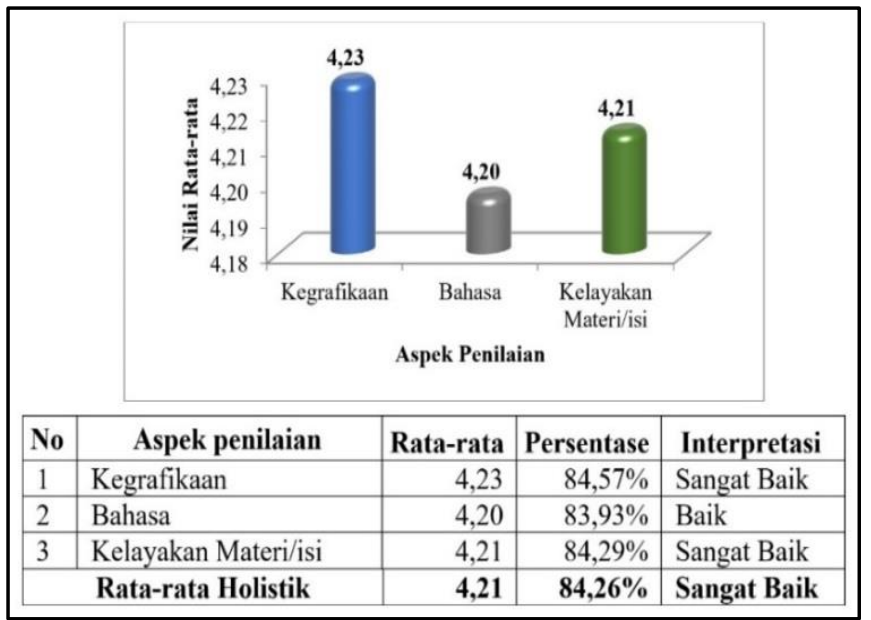

Figure 5. The analysis of the teachers book practicality BKpTSK [27]

Based on the figure, it showed that the results of the analysis of practitioners 'assessments of the lecturers' book prototype based on the BKpTSK model have very good interpretations with a holistic average value of 4.21. From the results of the assessment on the aspects of the grammar assessment of the lecturer book prototype based on the BKpTSK model, it has the highest average score of 4.23 with very good interpretation. This indicates that it has a good layout and visually the lecturers' books based on the BKpTSK model are attractive. Meanwhile, the lowest average score is in the aspect of language assessment with an average score of 4.20 and good interpretation.

\section{c. BKpTSK Students Book}

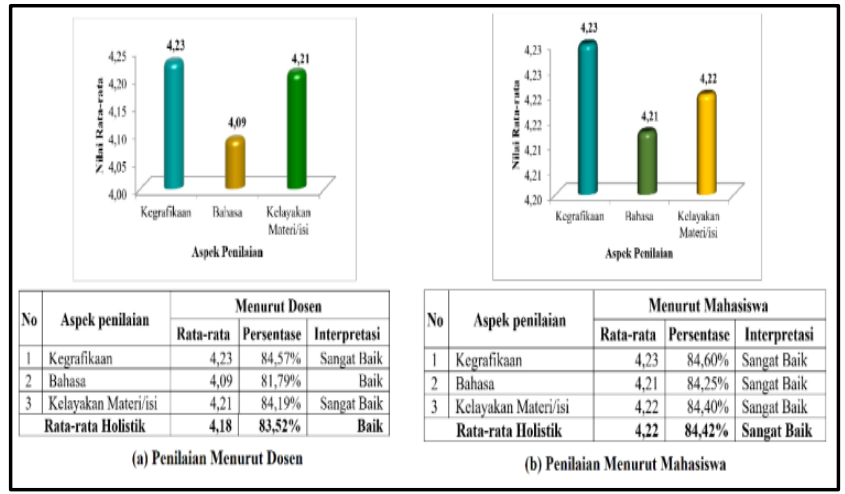

Figure 6. The analysis of the students book practiaclity BKpTSK [27]

The Figure above shows the results of the analysis of the practitioner (BK lecturers) assessment of the student book prototype based on the BKpTSK model have a good interpretation with a holistic average score of 4.18. Meanwhile, the student's assessment of the student book prototype based on the BKpTSK model has a very good interpretation with a holistic average score of 4.22 According to BK lecturers and students, the graphic aspects of the student book based on the BKpTSK model have the highest average score with very good interpretation. Whereas the lowest average score is in the aspect of language assessment with an average score of 4.18 assessments from lecturers and an average score of 4.22 assessments from students.

\section{DISCUSSION}

The development stage is related to the validity test results of the BKpTSK prototype model. The first discussion at the development stage relates to the finding of the validity test results on the BKpTSK model book prototype. The validity of the BKpTSK model book prototype has valid criteria with a holistic Aiken index of 0.815 . The aspect of assessing the theory supporting the BKpTSK model described in the book has the highest Aiken index with a value of 0.875 and very valid criteria. These findings indicate that the use of scientific theory/basis that supports the development of the BKpTSK model syntax has good and clear relevance. Furthermore, the reliability of the validator's assessment of the BKpTSK model book prototype has good criteria, this is evidenced by the calculation of the ICC coefficient on the BKpTSK model book obtained a value of 0.729 .

Published By:

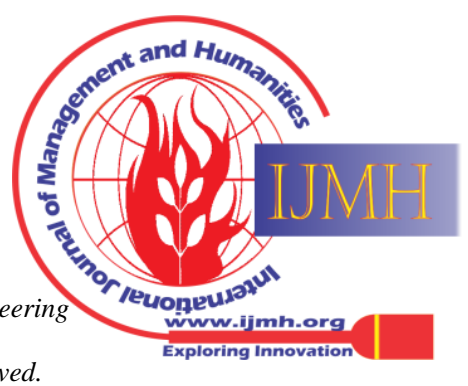


The findings from the validity and reliability test results of the BKpTSK model book above show that the BKpTSK model book prototype has valid, reliable and usable criteria because in the development of the model book it has fulfilled the six components of the model such as the syntax component of reaction principles, social systems, support systems, instructional and accompaniment impact [4] [26].

The results of the assessment on the syntactic aspects of the BKpTSK model also have very valid criteria with an Aiken index of 8.42. These results indicate that the developed learning model syntax contains a logical sequence of learning activities and is likely to be carried out properly by lecturers and students so that they can improve critical thinking and problem-solving skills through the steps of Conflict, Investigation, Negotiation, and Resolution. Furthermore, the results of the validity test of the BKpTSK model book on the assessment aspect of the model support system also have very valid criteria with an Aiken index of 0.857. This shows that lecturers and students have the opportunity to implement the BKpTSK model because it is supported by Lecturer and Student Books. Model support systems have a major contribution to the successful application of learning models (Joyce and Weil 1992).

The second discussion at the develop stage is related to the validity of the Lecturer Book prototype. In general, the validity test of the lecturer's book prototype has valid criteria with a holistic Aiken index of 0.828 . The results of the assessment of the content feasibility aspect of the lecturer's book have the highest Aiken index with a value of 0.875 and the criteria are very valid. This indicates that the material construction on the Lecturer Book prototype is systematically sorted according to the syllabus and SAP. The next findings relate to the reliability of the validator's assessment of the lecturer's book prototype, the findings on the reliability test of lecturers 'books, in general, have good criteria, this is evidenced by the results of the calculation of the ICC coefficient on the lecturers' book, the value is 0.746 .

Based on the description above, it can be explained that the findings from the validity and reliability test results show that the lecturers' book prototypes have valid and reliable criteria. With reference to the basic Kepmendiknas Number: 36 / D / O / 2001 Article 5 concerning the development of teaching materials, testing the validity and reliability of lecturers 'books from the aspects of content assessment, language, and lecturers' book graphics can be used in learning.

The third discussion at the development stage is related to finding the results of the validity test of the Student Book prototype. The findings on the results of the validity test of student book prototypes generally have valid criteria with a holistic Aiken index of 0.814 . The results of the assessment of the content feasibility aspect of the student book have the highest Aiken index with a value of 0.844 and the criteria are very valid. These findings indicate that the material construction in the student book prototype has complete material coverage in accordance with the counseling guidance course curriculum. The next findings relate to the reliability of the validator's assessment of the student book prototype, the findings on the reliability/consistency test of lecturers' book has good criteria, this is evidenced by the results of calculating the ICC coefficient on student books obtained a value of 0.705 .

Based on the description above, the results of the validity and reliability test of student books show that the prototypes of student books generally have valid and reliable criteria. By referring to the Kepmendiknas Number: 36 / D / O / 2001 article 5 regarding the development of teaching materials, student books can be used in learning because their validity and reliability have been tested.

Based on the above discussion, there are no fundamental changes to the prototype of the BKpTSK model and its components which include syntax, social systems, reaction principles, instructional impact support systems, and the accompanying impact of the model. After going through the assessment of the validator team, the practitioner team will then evaluate several support systems. Construct validity is the logical relationship between content validity and consistency [23].

\section{The practicality test of the 1st BKpTSK model}

The implementation of the implement stage is related to the results of the 1st practicality test of the BKpTSK prototype model which was carried out through limited trials involving 26 students. The first discussion at the implementation stage is related to the findings of the practicality test on the student book prototype. The practicality of student book is assessed from six practical aspects, namely: 1) instructions, 2) objectives, 3) material, 4) language, 5) graphics, and 6) practicality of the benefits of student books.

Based on the practicality test results of the student book prototype, it has practical criteria with a holistic average score of 4.19 and a holistic percentage of $83.80 \%$ practical achievement. The highest average assessment is in the material aspect with a value of 4.27 and the criteria are very practical, this indicates that the material construction on the student book prototype has a coherent and clear arrangement according to the syllabus, so that it can help students to understand the material on Counseling Guidance.

The second discussion at the implement stage relates to the findings of the practicality test on the prototype of the knowledge test questions used as an evaluation instrument in the implementation of the BKpTSK model. The practicality of the knowledge test questions was assessed from five practical aspects, namely: 1) The suitability of the test questions, 2) the content of the test questions 3) The difficulty level of the test questions, 4) the construction of the language used in the test questions, and 5) the estimated time for completing the test questions. The findings on the practicality test results of the prototype of knowledge test questions have practical criteria with a holistic average score of 4.14 and the percentage of practical holistic achievement of $82.77 \%$. The highest average assessment is in the content aspect of the test items with a value of 4.27 and the criteria are very practical, this indicates that the concept construction used in writing the questions is correct and in accordance with the Counseling Guidance material. In addition, the formulation of questions is communicative and the questions are made relevant to the learning indicators.

Blue Eyes Intelligence Engineering

\& Sciences Publication

(C) Copyright: All rights reserved. 

knowledge test questions carried out by students were considered practical, there were several important inputs that researchers got from students, namely: (1) the level of difficulty of the questions used needed to be considered again; (2) in writing questions, students still find the use of words that are difficult for students to understand and (3) The number of questions and the level of difficulty in the questions is not comparable to the 90 minutes time allocation The three points above are used as references in the revision of knowledge test questions before the broad trial is carried out.

\section{Second practicality test and effectiveness of the BKpTSK model}

The results of data analysis at the evaluation stage were related to the findings in the 2nd practicality test and the effectiveness test of the BKpTSK prototype model. The following is a discussion of the research findings on practicality 2 and the effectiveness test of the BKPTSK prototype model.

\section{a. The practicality test of both BKpTSK model}

The second practicality test was carried out through extensive trials, the first discussion at the efficacy stage was related to the findings of the practicality test results on the student book prototype used in the normal implementation of the BKpTSK model.

The findings on the practicality test results of the 2 student book prototypes have very practical criteria with a holistic average score of 4.24 and a holistic achievement percentage of $84.76 \%$. The highest average value is 4.28 in the assessment aspect of material construction with a very practical interpretation. The findings of these results apply to the results of the 1st practicality test which means that the material in the student book prototype has a coherent and clear arrangement in accordance with the syllabus so that it can help students to understand the material on Counseling Guidance. Some of the responses from practitioners to student books were very positive, while the responses included 1) student books were very useful for the implementation of the BKpTSK model; 2) interesting book material to study, and 3) the material in student books is very helpful and easy for me. In addition, the material in the book has been explained in detail.

The second discussion in the evaluation stage relates to the finding of the practicality test results of the Lecturer Book prototype used in the learning process of the BKpTSK model. The findings on the practicality test results of lecturers' book prototypes generally have practical criteria with an average value of 4.18 and the percentage of holistic achievement of $82.77 \%$ practical. The highest average value is 4.50 and the percentage of practicality achievement is $90.00 \%$ in the aspect of syntax explanation with very practical interpretation. This means that the existence of practical lecturer books and helps lecturers to understand and apply the syntax of the BKPTSK model in learning. According to Joyce, Well \& Calloon (2016) implicitly states that one of the characteristics/indicators of a good model is the ease of using a support system to implement the learning model syntax.

The third finding at the evaluation stage is related to the practicality test results of the implementation of the BKpTSK prototype model in normal learning from the
From the results above, although in general the

student's point of view. The findings of the practicality test of the implementation of the BKpTSK prototype model from the student's point of view generally have very practical criteria with an average value of 4.22 and a percentage of holistic achievement of $84.31 \%$. The highest average value is 4.23 in the implementation aspect of the BKpTSK syntax model, this shows that students can follow the syntax stages of the BKpTSK model carried out by lecturers and can achieve learning objectives through the application of the BKpTSK syntax model.

The fourth discussion in the evaluation stage is related to the practicality test results of the BKpTSK prototype model carried out by lecturers in normal learning. The findings of the practicality test of the BKpTSK prototype model carried out by lecturers in normal learning generally have very practical criteria with an average value of 4.23 and the percentage of holistic achievement of $84.58 \%$. There are two aspects that have a very practical assessment on the practicality test of the BKpTSK prototype model carried out by lecturers, namely 1) the aspect of assessing the implementation of the allocation of time in learning and 2) the implementation of the syntax of the BKpTSK model with an average value of 4.50 and 4.25. This shows that Lecturers can carry out the stages in learning with the BKpTSK model according to the set time allocation, and Lecturers can help students to achieve learning goals through the application of syntax in the BKpTSK model.

The fifth discussion in the evaluation stage is related to the findings of practicality test results on the prototype of knowledge test questions used as an evaluation instrument in the implementation of the BKpTSK model. The findings on the practicality test results of the prototype of knowledge test questions, in general, have very practical criteria with a holistic average score of 4.24 and a holistic achievement percentage of $84.79 \%$. The maximum average value in the practicality test of the test items is 4.25 with very practical criteria in the aspect of the content of the test questions. The results of this calculation provide information that the concept construction used in writing the questions is correct and in accordance with the Counseling Guidance material, the formulation of questions is communicative and the questions made are relevant to the learning indicators.

Further findings obtained that the results of the assessment of practicality aspects of the difficulty level of the questions, language, and time also have very practical criteria with values of $4.23,4.32$, and 4.22 . These findings also indicate that the construction of the questions was arranged with various difficulty levels (medium difficulty and easy), the writing on the test questions used language that was easy to understand, and the proportion of time allocation was in accordance with the number and level of difficulty of the questions.

Based on the explanation above, the researcher made revisions according to the comments and suggestions of practitioners, to get a model support system that is practical and suitable for use in learning. The product is said to be practical if the practitioner views and assesses the resulting product is easy to use and can be useful in learning [6] [9].
Blue Eyes Intelligence Engineering

(C) Copyright: All rights reserved.
\& Sciences Publication 


\section{b. Discussion on the practicality of implementing the BKpTSK syntax model}

The implementation of the whole syntax of the BKpTSK model on a broad trial begins with the conflict stage. The conflict stage includes several activities, such as forming study groups, looking for examples of conflicts that occur in the community; as well as criticizing and understanding in detail the conflict by reading and compiling a summary of teaching materials to obtain conflict formulations. Reading activities and compiling a summary of material related to conflict enables students to understand the problem/conflict [2] [4] [9] [12] [16] [17] states that taking notes on the conflict in learning can train students to be skilled in critical thinking. With learning activities that take place at the conflict stage, the BKpTSK model provides opportunities for students to think critically in understanding conflict.

The second activity at the BKpTSK model stage is investigative activities. The findings at the investigation stage appear to be able to carry out learning activities such as collecting and analyzing information from various credible literacy sources to obtain a design solution to the conflict; hold discussions to design solutions that can be taken in resolving conflicts. The activity of exploring the problem (explore the problem) by collecting information from various credible literacy sources can train students to formulate solution plans of problems/conflicts [8] [10] [15]. The investigation phase ends by creating and completing a draft solution plan which is represented on the conflict solution design report sheet.

The third stage in the BKpTSK model syntax is negotiation. From the results of the observations at the negotiation stage, the researcher found that students were able to present a draft conflict solution design, have discussions on the draft conflict solution design with other groups to come up with ideas, concepts, and alternative solutions to solve conflicts that are mutually beneficial (winwin). solution) then students make a report on discussion activities to produce an agreement on alternative solutions to mutually beneficial conflicts. Through discussion activities and presenting conflict solution designs at the negotiation stage, students can practice communication skills, collaboration, and critical thinking skills. This is relevant to the findings in research [18] and [23] which state that presenting work results in the form of a solution design can teach students to be skilled at communicating well.

The last activity in implementing the BKpTSK model is the resolution stage. At this stage, students are seen as being able in groups to evaluate, reflect and make final solutions (conclusions) to the results of negotiation activities. Evaluation, reflection, and making final solutions in learning can help students practice critical thinking skills and solve problems [6] [9] [11] [15] [19].

\section{CONCLUSION}

Based on the objectives, results, and discussion of the research that has been described, the following can be concluded:

1. A Group Guidance Model to Prevent Potential Homosexual Threats in Higher Education has been produced through the ADDIE development model.

2. The model of Group Guidance to Prevent Potential Homosexual Threats in Higher Education that has been produced has an average value of 0.80 valid. The model book has an average score of 0.817 and is classified as valid. The student book has an average score of 0.796 and is classified as valid. The student book has an average score of 0.794 and is classified as valid. The practicality of the research product has an average score of 4.2 and is classified as very practical. The model book has an average score of 4.20 and is classified as very practical. Lecturer book has an average score of 4.21 and is classified as very practical. The student book has an average score of 4.20 and is classified as very practical.

\section{ACKNOWLEDGMENT}

Thank you very much to the promoter lecturer, Prof. Dr. Nevi Yarni, and Prof. Dr. Muri Yusuf. thanks to their guidance and care, this article was finally completed. Thank you also to all the academicians of Padang State University who have helped a lot in completing this article.

\section{REFERENCES}

1. Brevetti, Melissa. 2014. Developing a Moral Compass:Experiences, Dialogues, and Reflection in Parochial Schools. Journal of Religious \& TheologicalInformation, vol.13. Issue 3/4, p59-78. 20p. http://web.b.ebschohost.com/ehost/delivery?sid=03cf8d4e-d456446f(Diakses pada tanggal 19 Desember 2016, 6 : 03 pm)

2. Breen, Margaret Sönser dan Fiona Peters. (2005). Genealogies of Identity: Interdisciplinary Readings on Sex and Sexuality.New York: Rodopi.

3. Byrd, A. Dean dan Stony Olsen.(2001). Homosexuality: Innate and Immutable. Regent UL Rev. 14.

4. Cameron, Paul dan Kirk Cameron. (2012). Re-Examining Evelyn Hooker: Setting the Record Straight with Comments on Schumm's Reanalysis. Marriage \& Family Review 48.6, hal 49.

5. Colman, Andrew M. (2009).A Dictionary of Psychology.New York: Oxford University Press.

6. Cotten, Christopher dan John W. Ridings.(2011). Getting Out/Getting In: The DSM, Political Activism, and the Socia Construction of Mental Disorders.dalam Social Work in Mental Health 9.3, hal 182

7. Cox, Harvey. (2013).The Secular City: Secularization and Urbanization in Theological Perspective. New Jersey: Princeton University Press.

8. Crompton, Louis. (2003).Homosexuality and Civilization.London: The Belknap Press Of Harvard University Press.

9. Cummings, Nicholas A. (2006).The APA And Psychology Need Reform. Makalah disampaikan pada Annual Convention Of The American Psychological Association (August 12). New Orleans, LA.

10. Gibson, R.L. dan Mitchell, M.H. (2011).Bimbingan dan Konseling: Terjemahan Introduction to Counseling and Guidance (Edisi Ketujuh). Yogyakarta: Pustaka Pelajar.

11. Hesley, J,W \& Hesley J.G. (2001). Rent Two Films and Let's Tallk in the Morning: Using Popular Movies in Psycotherapy (2nd) NY:Wiley and Sons.

12. Minton, Henry L.,(2002). Departing from Deviance: A History of Homosexual Rights and Emancipatory Science in America, (Chicago:The University of Chicago.

13. Muhammad, Husein et al, Fiqh Seksualitas Risalah Islam untuk Pemenuhan Hak-hak Seksualitas, (tt: PKBI, tth)

14. Myers, Joanne. (2003).Historical Dictionary of the Lesbian Liberation Movement Still the Rage.USA:Scarecrow Press.

15. National Association for Research and Therapy of Homosexuality (US).Scientific Advisory Committee, et al. (2009).What Research Shows: NARTH'sResponse to the APA Claims on Homosexuality: a Report of the Scientific Adisory Committee of the National Association for Research and Therapy of Homosexuality. National Association for Research and Therapy of Homosexuality.

Published By:

Blue Eyes Intelligence Engineering

\& Sciences Publication

(C) Copyright: All rights reserved. 
16. Richards, R. Scott dan Allen E. Bergin. (2007).A Spritual Strategy for Counseling and Psychoteraphy Second Edition, (Washington DC:American Psychological Asosiation.

17. Rosario, Vernon A. (2002).Homosexuality and Science: A Guide to the Debates, Calivornia: ABC-CLIO.

18. Rönn, Minttu, et al. (2014). Developing A Conceptual Framework Of Seroadaptive Behaviors In HIV-Diagnosed Men Who Have Sex With Men. Journal of Infectious Diseases 2.10.hal 586

19. Sampson, Mark et al. (2006). Personality Disorder and Community Mental Health Teams: A Practitioner's Guide. New Jersey:John Wiley and Sons.

20. Satinover, Jeffrey. (1996).Homosexuality and the Politics of Truth .tt: Baker Books.

21. Spencer, Colin. (2011)Sejarah Homoseksualitas dari Zaman Kuno hingga Sekarang, diterj oleh Ninik Rochani Sjams. Bantul:Kreasi Wacana.

22. Spitzer, Robert L. (2003).Can Some Gay Men And Lesbians Change Their SexualOrientation? 200 Participants Reporting A Change From Homosexual To Heterosexual Orientation. Archives of sexual behavior 32.5 : 403-417.

23. ..(2012).Spitzer Reassesses His 2003 Study Of Reparative Therapy Of Homosexuality Archives of sexual behavior.

24. Soebagio, Rita, LGBT dan RUU KKG,http://www.republika.co.id/berita/koran/islamia/14/09/18/nc2z 89-lgbt- dan-ruu-kkg) diakses 25 Desember 2014.

25. Homophobia (http: // thisisgender. com/ kampanye-lesbiberkemasan psikologi/)diakses25Desember 2014.

26. Zachar, Peter dan Kenneth S. Kendler. (2012).The Removal Of Pluto From The Class Of Planets And Homosexuality From The Class Of Psychiatric Disorders: A Comparison.dalamPhilos Ethics Humanit Med 7.4 .

27. Widoyoko. 2017. Teknik Penyusunan Instrumen Penelitian Yogyakarta, Pustaka Pelajar

28. Zijlstra, Iris. (2014). The Turbulent Evolution Of Homosexuality: From Mental Illness To Sexual Preference." Dalam, Social Cosmos 5.1

\section{AUTHORS PROFILE}

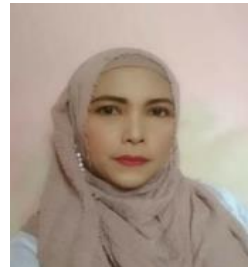

Nama; Hidayani Syam

Titel; mahasiswa

Lahir pada 28 Agustus 1982 di Padang.

Penulis adalah salah seorang dosen di Institut Agam Islam Negeri Bukittinggi. Latar belakang pendidikan penulis adalah gelar sarjana dalam Pendidikan Agama Islam pada tahun 2000. Judul skripsi yang ditulis adalah Peran Wali kelas di Madrasah (Studi kasus di MTsN Parak Laweh Padang). Beliau memiliki pendidikan magister di Bimbingan Konseling pada tahun 2009. Judul tesis yang ditulis adalah Persepsi dan Harapan Warga Binaan Narkoba terhadap Pembinaan di LP Klas IIA Padang. Selain mengajar, penulis juga melakukan penelitian dan pengabdian kepada masyarakat . Hari ini Penulis sedang menyelesaikan program doktor dibidang ilmu Pendidikan. Beberapa karya tulis seperti;

1. Group guidance modal with cinema councelling technique as a prevention of gay influence for students.

2. Group guidance modal with cinema councelling technique as a prevention of lesbianism influence for students.

3. Relevance and implementation of rural funding allocation in west pasaman regency after the law of No.6 year 2004 on Desa

4. Relevance and implementation of rural funding allocation in west pasaman regency after implementation of law desa.

5. Komunikasi dalam Konseling Lintas Budaya menghadapi masyarakat ekonomi asean (MEA).

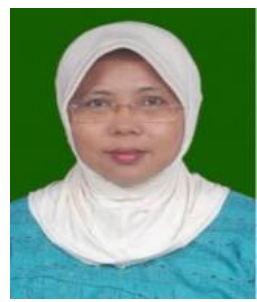

Name: Neviyarn

Tittle: Professor

Lahir pada 09 November 1955 di Bukittinggi.

Beberapa artkel yang telah ditulis seperti

1. Efektivitas layanan informasi dengan menggunakan metode blended learning untuk meningkatkan motivasi belajar

2. Peranan seorang guru dalam menciptakan lingkungan bekajar yang kondusif 3. Hubungan antara kecerdasan emosi dengan perilaku agrsif remaja dan implikasinya dalam bimbingan dan konseling
4. Hubungan gaya belajar dan keterampilan belajar dengan hasil belajar mahasiswa serta implikasinya dalam Pelayanan Bimbingan dan Konseling di Fakultas Ilmu Pendidikan Universitas Negeri Padang.

5. Motif siswa memiliki smartphone dan penggunaannya.

6. Locus of Control dan perilaku menyontek serta implikasinya terhadap bimbingan dan konseling (Studi pada Siswa sekolah menengah atas padang ganting)

7. Peningkatan hasil belajar melalui dinamika kelompok dalam perkuliahan pengajaran psikologi dan bimbingan konseling (PPBK).

8. Pelayanan Bimbingan dan Konseling Berorientasi Khalifah fil Ardh

9. Kontribusi motivasi berprestasi terhadap regulasi diri siswa membolos di madrasah aliyah neegeri 2 Payakumbuh serta implikasinya terhadap layanan Bimbingan dan Konseling.

10. Efektivitas layanan bimbingan kelompok untuk meningkatkan motivasi belajar dan mengurangi perilaku membolos mahasiswa.

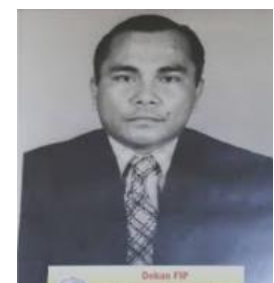

Nama: Muri Yusuf

Titel: Professor

Lahir di Pasaman, 16 September 1942. Beberapa karya beliau antara lain

1. Metode penelitian kuantitatif, kualitatif \& penelitian gabungan

2. Asesmen dan evaluasi pendidikan.

3. Metodologi penelitian: dasar-dasar penyelidikan ilmiah

4. Kiat sukses dalam karir

5. Evaluasi Pendidikan

6. Hubungan gaya belajar dan keterampilan belajar dengan hasil belajar mahasiswa serta implikasinya dalam Pelayanan Bimbingan dan Konseling di Fakultas Ilmu Pendidikan Universitas Negeri Padang.

7. Hubungan perencanaan karier dan efikasi diri dengan kesiapan kerja mahasiswa.

8. Pemahaman konselor sekolah tentang tugas perkembangan siswa dan layanan yang diberikan.

9. Hubungan antara Locus of Control dan efektifitas komunikasi antar pribadi dengan problem focused coping

10. Pengaruh layanan bimbingan kelompok terhadap pencapaian tugas perkembangan remaja awal dalam kemandirian emosional (Studi eksperimen di SMP Frater Padang)

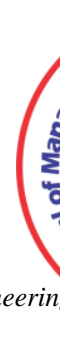

